\title{
THE INFLUENCE OF CUTTING PARAMETERS ON SURFACE TOPOGRAPHY DURING TURNING MARINE PUMP SHAFTS
}

\author{
Wojciech Labuda \\ Gdynia Maritime University, The Faculty of Marine Engineering \\ Morska Street 83, 81-225 Gdynia, Poland \\ tel.: +4858 5586549., fax: +48585586399 \\ e-mail:w.labuda@wm.umg.edu.pl
}

\begin{abstract}
One of the greatest problems of modern production techniques is the achievement of an appropriate quality at minimal costs and accompanied by the production efficiency increase. Therefore, while designing the production process. The technology used should have a considerable influence on the durability and reliability of machine parts to be produced. During finish treatment, the final dimensions as well as functional properties are imparted to a given element by application of proper treatment type. The engineer has a range of production techniques to choose for the proper surface layer formation. Conventional turning machines belong to the basic equipment of ships, because in sea conditions, they enable the execution of a spare part or carrying out the necessary operations in the process of their regeneration. The use of modern cutting tools makes it possible to obtain a surface with low values of surface roughness parameters. The use of new generation cutting inserts on conventional lathes can cause problems for operators. The lack of the ability to ensure proper of treatment condition and setting errors of cutting tools contribute to the damage of the cutting insert or the surface of the workpiece. The article presents the results of influence of different cutting parameters on surface topography during turning process of stainless steel. A shaft made of $304 \mathrm{~L}$ stainless steel was used for the research. The cutting process was carried out on a universal TUM $25 B x 500$ centre lathes. During the turning the following machining parameters were used: cutting speed $V c$ [m/min], feed $f$ [mm/rev] and depth of cut ap [mm].The turning process was conducted by a cutting tool with CCGT 09T302 UM, CCGT $09 T 304$ UM and CCGT 09T308 UM inserts. Measurement of surface topography was carried out by T8000 profilometer.
\end{abstract}

Keywords: finish turning process, surface topography, cutting parameters, stainless steel

\section{Introduction}

Due to hard service conditions, marine pumps working in seawater environment are made of corrosion resistant materials. In spite of the fact that pump shafts are made of an expensive material, it is not possible to avoid service damage. This damage includes cracking, plastic deformation, excessive wear of pins in places of mounting rotor discs and sealing chokes, corrosive wear, friction wear, erosive wear and splineways knock outs. During service experience, the most common problem that is observed is excessive wear of pins causing their diameter decrease as well as exceeding the permissible shape deviations in place of chokes mounting.

Many scientific centres, including Gdynia Maritime University, deal with issues related to the turning surface of the difficult-to-machine [1-13]. The research aims to determine a set of input factors, fixed and distorting for the finish lathing of pins shafts made of stainless steel, had an impact on geometrical structure of the surface, as well as on the values of forces and cutting temperature. Machining stainless steels, especially austenitic steel causes many difficulties. On the machinability of austenitic steel has a negative impact high propensity to the deformation strengthening, low thermal conductivity and good ductility. Alloying element improves the machinability of stainless steels is sulphur. Sulphur in combination with manganese forms $\mathrm{MnS}$ manganese sulphide, which positive influence on machinability is confirmed by the type of chips (short and brittle), smoother surfaces of workpieces and less tool wear. 
For the basic method of the surface layer, forming of shaft pins is known lathing. Conventional machining accuracy is usually considered as a function of the characteristics of all the components of machine tool, fixture, object and tool. There are accuracy performance and the accuracy of static and dynamic determining and cutting parameters, which are associated with strength, temperature and wear of the cutting edge. Therefore, stock removal of high efficiency should be performed in a controlled manner, which ensures the correct shape and size of the chip.

The geometric structure of the surface is one of the most important factors that determine the quality of the surface. It describes a set of all inequalities that overlap, formed during the machining processes and wears of the item.

The article is a continuation of the research on influence of changing the treatment condition during turning process of stainless steel. The article presents the results of influence of change of cutting parameters and nose radius during turning of shafts on Sa parameter.

\section{The research methodology}

During research of surface roughness parameters, the shafts made of stainless steel (304L) were used (Fig. 1). The process of turning was carried out on a universal TUM 25B x 500 lathe centre. The lathing process was conducted by a cutting tool with CCGT 09T302 UM, CCGT 09T304 UM and CCGT 09T308 UM inserts. In order to analyse of influence change of cutting parameters for UM insert on the obtained surface topography parameter Sa (arithmetical mean height of the surface) was used. The cutting parameters dedicate for turning process by producer were presented in Tab. 1.

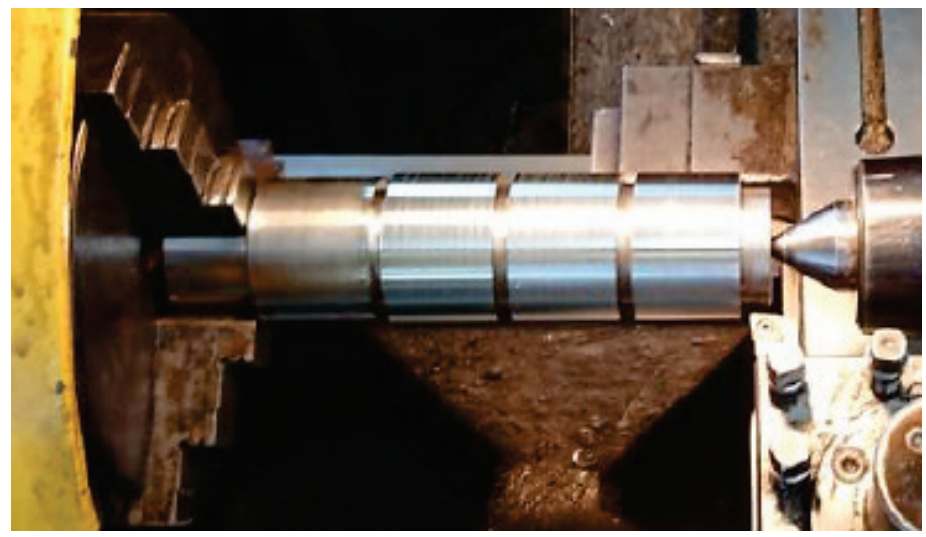

Fig. 1. The sample used for turning process

Tab. 1. The cutting parameters dedicate for turning process

\begin{tabular}{|c|c|c|c|c|}
\hline \multicolumn{2}{|c|}{ Type of inserts } & \multicolumn{3}{c|}{ Cutting parameters } \\
\cline { 2 - 5 } & Vc [m/min] & $\mathrm{f}[\mathrm{mm} / \mathrm{rev}]$ & $\mathrm{ap}[\mathrm{mm}]$ \\
\hline \multirow{4}{*}{} & CCMT 09T302 UM & 220 & 0.07 & 0.3 \\
1125 & $(225-165)$ & $(0.02-0.12)$ & $(0.3-3)$ \\
\cline { 2 - 5 } & CCMT 09T304 UM & 205 & 0.15 & 1.3 \\
1125 & $(225-155)$ & $(0.08-0.25)$ & $(0.3-3)$ \\
\cline { 2 - 5 } & CCMT 09T308 UM & 180 & 0.20 & 1.3 \\
& 1125 & $(215-120)$ & $(0.12-0.35)$ & $(0.3-3)$ \\
\hline
\end{tabular}

During the turning process, the following machining parameters were used: cutting speed (Vc), feed (f) and depth of cut (ap). The values of cutting parameters are presented in Tab. 2. The turning process was carried out for two cutting speeds $\mathrm{Vc}=140$ and $\mathrm{Vc}=197 \mathrm{~m} / \mathrm{min}$. The value of depth of cut ap $=0.5 \mathrm{~mm}$ was determined for the finishing turning process. 
Tab. 2. The cutting parameters used in turning process

\begin{tabular}{|c|c|c|c|c|c|}
\hline \multirow{2}{*}{\multicolumn{2}{|c|}{ Number of shaft pins }} & \multirow{2}{*}{$\begin{array}{c}\text { Nose radius } \\
\mathrm{r}[\mathrm{mm}]\end{array}$} & \multicolumn{3}{|c|}{ Cutting parameters } \\
\hline & & & \multicolumn{2}{|c|}{\begin{tabular}{l|l}
$\mathrm{fn}[\mathrm{mm} / \mathrm{rev}]$ & ap $[\mathrm{mm}]$
\end{tabular}} & \multirow{2}{*}{$\mathrm{Vc}[\mathrm{m} / \mathrm{min}]$} \\
\hline \multirow{3}{*}{ Shaft1 } & pin 1 & \multirow{3}{*}{0.2} & 0.04 & \multirow{18}{*}{0.5} & \\
\hline & $\operatorname{pin} 2$ & & 0.08 & & \multirow{8}{*}{140} \\
\hline & $\operatorname{pin} 3$ & & 0.14 & & \\
\hline \multirow{3}{*}{ Shaft 2} & pin 1 & \multirow{3}{*}{0.4} & 0.04 & & \\
\hline & $\operatorname{pin} 2$ & & 0.08 & & \\
\hline & $\operatorname{pin} 3$ & & 0.14 & & \\
\hline \multirow{3}{*}{ Shaft 3} & pin 1 & \multirow{3}{*}{0.8} & 0.08 & & \\
\hline & $\operatorname{pin} 2$ & & 0.04 & & \\
\hline & $\operatorname{pin} 3$ & & 0.14 & & \\
\hline \multirow{3}{*}{ Shaft 4} & pin 1 & \multirow{3}{*}{0.2} & 0.04 & & \multirow{9}{*}{197} \\
\hline & $\operatorname{pin} 2$ & & 0.08 & & \\
\hline & $\operatorname{pin} 3$ & & 0.14 & & \\
\hline \multirow{3}{*}{ Shaft 5} & pin 1 & \multirow{3}{*}{0.4} & 0.04 & & \\
\hline & $\operatorname{pin} 2$ & & 0.08 & & \\
\hline & $\operatorname{pin} 3$ & & 0.14 & & \\
\hline \multirow{3}{*}{ Shaft 6} & pin 1 & \multirow{3}{*}{0.8} & 0.04 & & \\
\hline & $\operatorname{pin} 2$ & & 0.08 & & \\
\hline & $\operatorname{pin} 3$ & & 0.14 & & \\
\hline
\end{tabular}

The surface topography was measured by T8000 profilometer. For the test used measuring tip with a $2 \mu \mathrm{m}$ radius. The analysis covered the parameter of surface topography $-\mathrm{Sa}$.

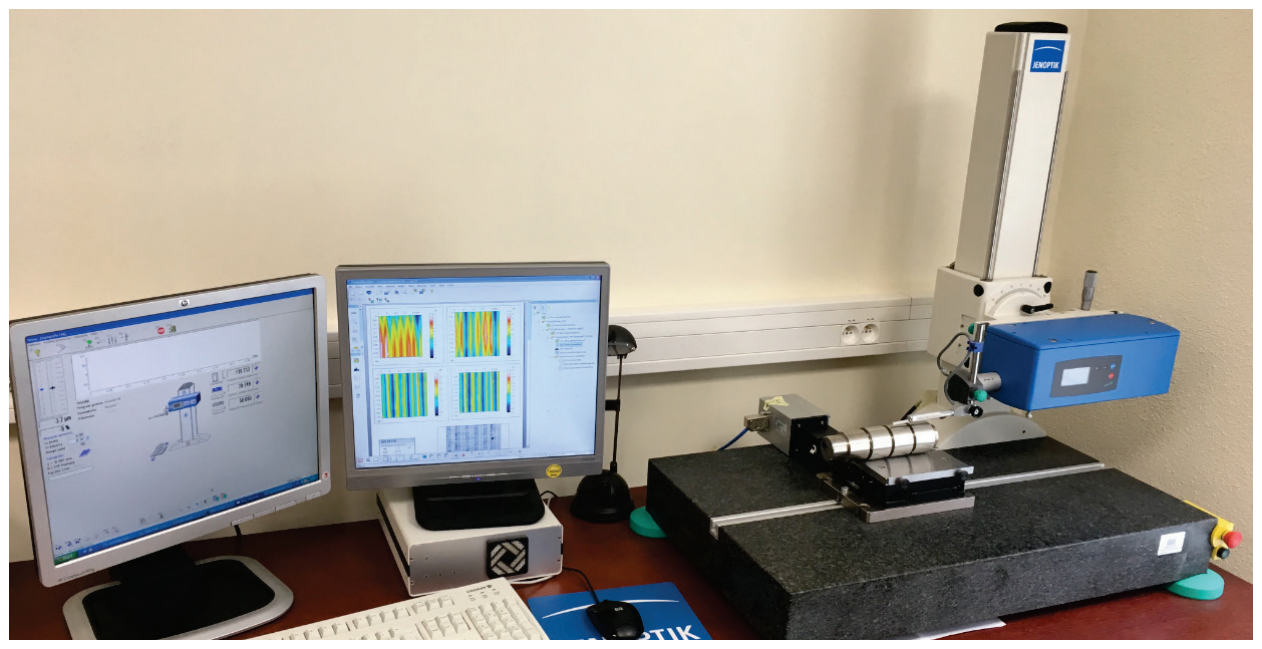

Fig. 2. T8000 profilometer

\section{The research results}

Figure 3 presents the results of the measurement of the surface topography parameter of selected shaft pins subjected to the turning process.

For cutting speed $\mathrm{Vc}=140 \mathrm{~m} / \mathrm{min}$ and depth of cut ap $=0.5 \mathrm{~mm}$, the highest value of Sa parameter $(1.97 \mu \mathrm{m})$ was obtained for the nose radius $\mathrm{r}=0.8 \mathrm{~mm}$ and feed $\mathrm{f}=0.04 \mathrm{~mm} / \mathrm{rev}$. Whereas, the lowest value of Sa parameter $(0.6 \mu \mathrm{m})$ for the turning process by the cutting insert with a nose radius $\mathrm{r}=0.8 \mathrm{~mm}$ and a feed $0.08 \mathrm{~mm} / \mathrm{rev}$ was observed. 


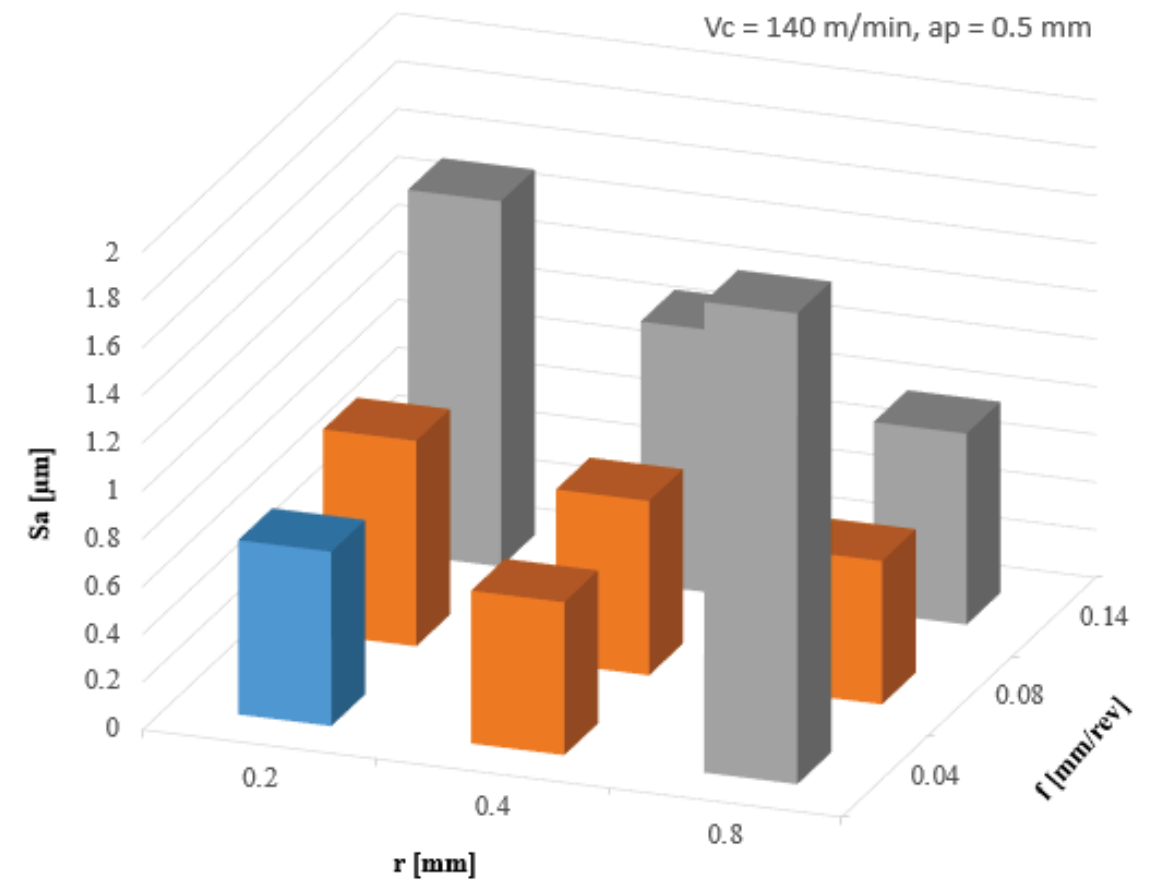

Fig. 3. The influence of treatment conditions on the parameter Sa for $V c=140 \mathrm{~m} / \mathrm{min}$

Figure 4 presents the surface topography of selected shaft pins submitted to the turning process with cutting speed $\mathrm{Vc}=140 \mathrm{~m} / \mathrm{min}$ and depth of cut ap $=0.5 \mathrm{~mm}$.

The highest value of the Sa parameter $(1.45 \mu \mathrm{m})$ was obtained for the corner nose $\mathrm{r}=0.8 \mathrm{~mm}$ and the feed $\mathrm{f}=0.04 \mathrm{~mm} / \mathrm{rev}$. whereas, the lowest value of Sa $(0.67 \mu \mathrm{m})$ for $\mathrm{r}=0.8 \mathrm{~mm}$ and the feed rate $0.08 \mathrm{~mm} / \mathrm{rev}$ was observed.

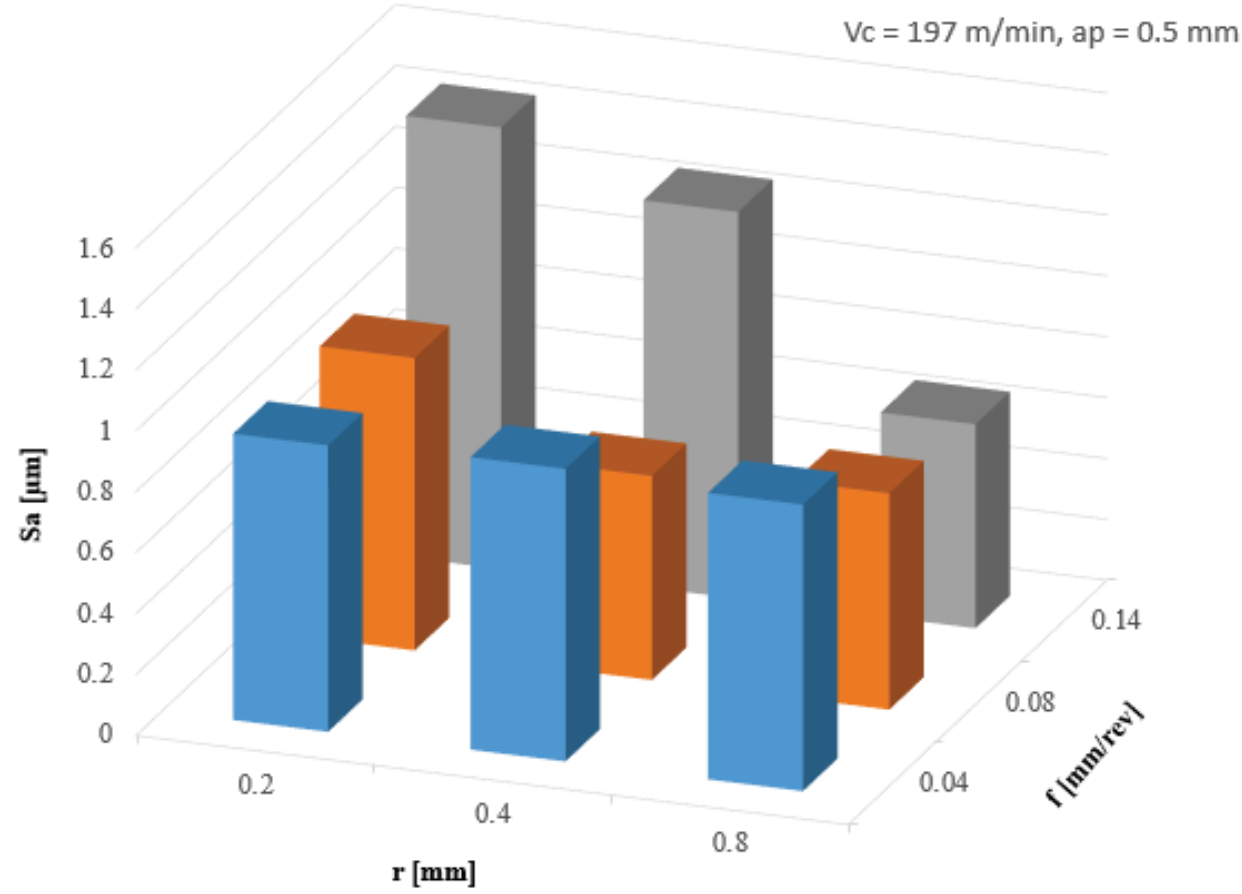

Fig. 4. The influence of treatment conditions on the parameter $S a$ for $V c=197 \mathrm{~m} / \mathrm{min}$

Figure 5 presents the results of surface topography measurements for which the lowest and highest value of the Sa parameter was obtained $(\mathrm{Vc}=140 \mathrm{~m} / \mathrm{min})$. The influence of unfavourable cutting conditions was observed for the turning process with $\mathrm{Vc}=140 \mathrm{~m} / \mathrm{min}$ and $\mathrm{f}=0.04 \mathrm{~mm} / \mathrm{rev}$. 
The surface topography shown, that the surface layer has not been removed in the entire cutting area. Increasing the value of feed above $0.08 \mathrm{~mm} / \mathrm{rev}$ stabilized the cutting edge during turning process and allowed to obtain a 3 times smaller value of the Sa parameter. On the surface of shaft pin traces features of the passage of the turning tool are visible.

Figure 6 presents the results of measurements of surface topography for turning process with cutting speed of $197 \mathrm{~m} / \mathrm{min}$. Traces on the surface of shaft pin testify to an even machining process for the cutting parameters used. The use of a variable value of feed and nose radius of cutting insert influenced the obtained values of the Sa parameter.

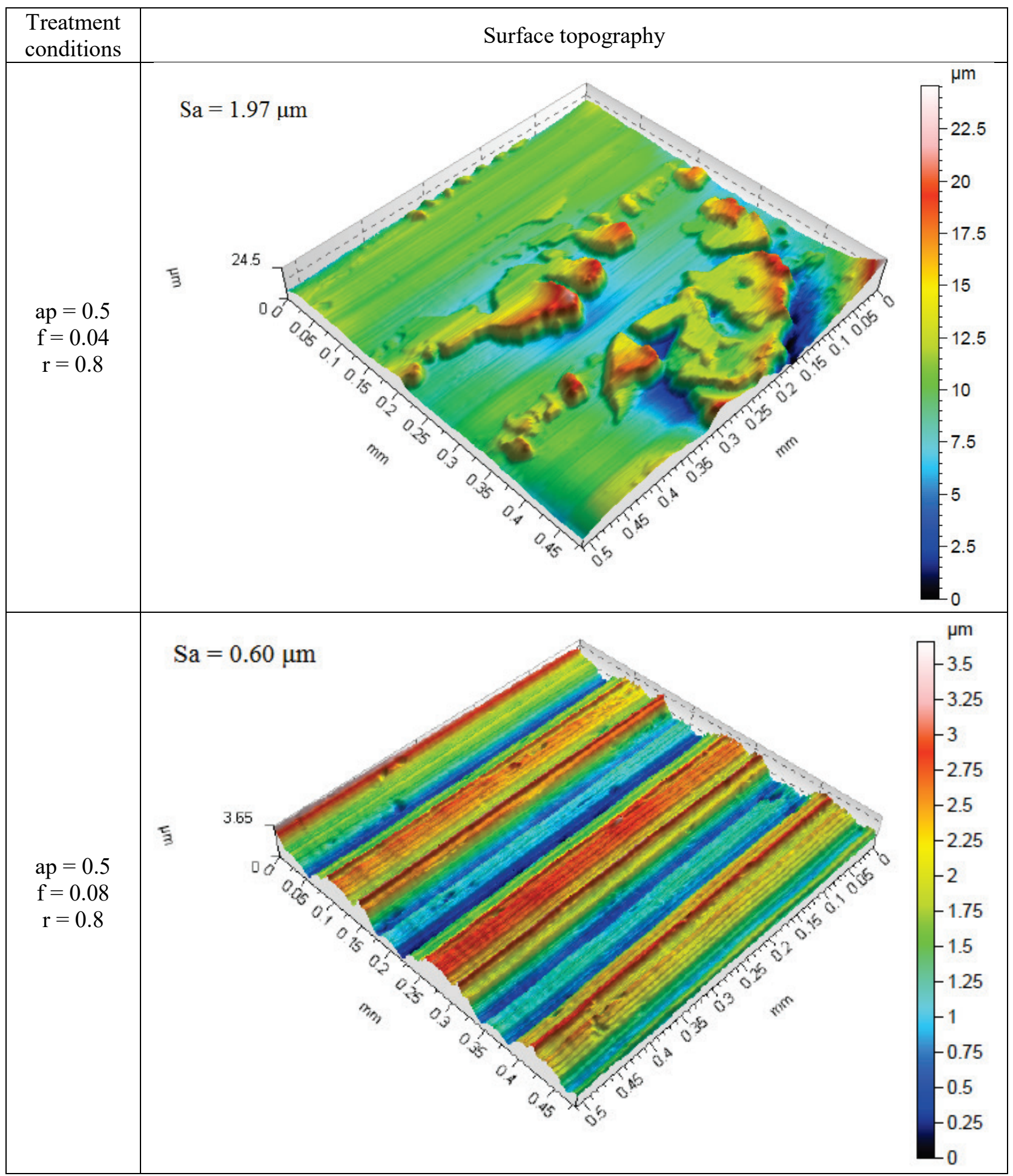

Fig. 5. Example view of the surface topography for $V c=140 \mathrm{~m} / \mathrm{min}$ 


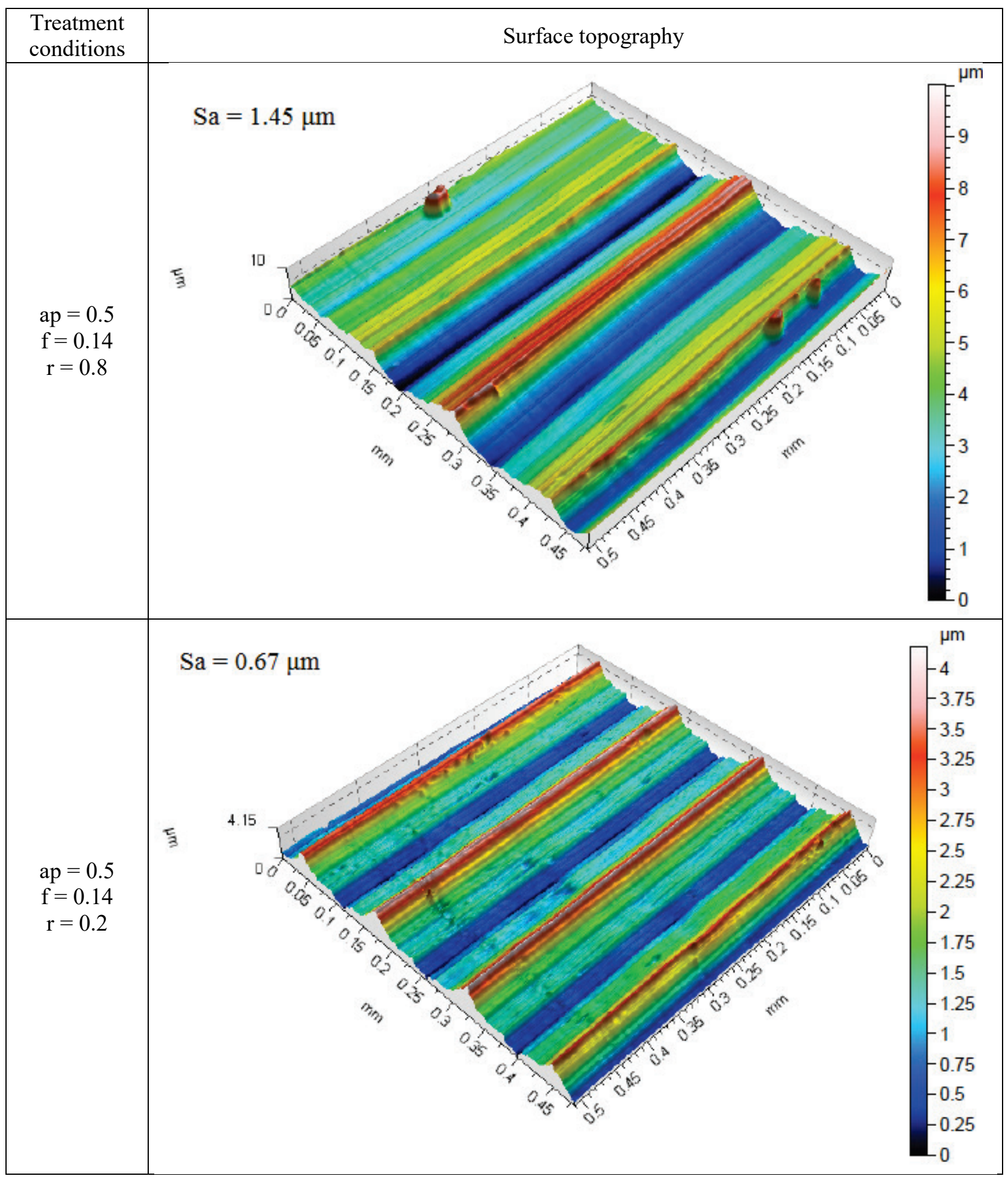

Fig. 6. Example view of the surface topography for $V \mathrm{c}=197 \mathrm{~m} / \mathrm{min}$

Obtained test results for the selected range of cutting parameters and different nose radius, allowed to obtain different values of the Sa parameter. For the highest value of feed $\mathrm{f}=0.14 \mathrm{~mm} / \mathrm{rev}$, with the increase of nose radius value, the value of the surface topography parameter decreased, both for $\mathrm{Vc}=197 \mathrm{~m} / \mathrm{min}$, as well as for $\mathrm{Vc}=140 \mathrm{~m} / \mathrm{min}$. For smaller feed values, no such a clear trend was observed. For the turning process with $\mathrm{Vc}=140 \mathrm{~m} / \mathrm{min}$, $\mathrm{ap}=0.5 \mathrm{~mm}, \mathrm{f}=0.04 \mathrm{using}$ the CCMT 09T308 UM insert, a low feed value was most likely the cause of a sharp increase on value of Sa parameter. The minimum value of feed for this insert should be $0.12 \mathrm{~mm} / \mathrm{rev}$. 


\section{Conclusions}

The turning process using the cutting insert on the conventional lathes requires the correct choice of the turning tool relative to the material and required quality of product. Analysis of the results showed significant differences in the values obtained for surface topography parameter during changing of cutting parameters and nose radius of insert.

In marine conditions, the possibilities of a wide selection of cutting tools are limited, therefore, it is important to choose correct cutting parameters and correct positioning of the cutting tool, especially on the conventional lathe.

Due to the limited rotational speed control on the conventional lathes and their maximum values, the operator should set the parameters for the cutting parameters and nose radius of insert in order to ensure adequate quality of the surface layer.

Improper treatment conditions contribute to the formation of ductile chips, which adversely affects the machining process. Most often, it destroys the quality of shaft pins surface.

\section{References}

[1] Agustina, B., Bernal, C., Camacho, A. M., Rubio, E. M., Experimental analysis of the cutting forces obtained in dry turning processes of UNS A97075 aluminium alloys, The Manufacturing Engineering Society International Conference, MESIC, Procedia Engineering, 63, pp. 694-699, 2013.

[2] Bensouilah, H., Aouici, H., Meddour, I., Yallese, M. A., Mabrouki, T., Girardin, F., Performance of coated and uncoated mixed ceramic tools in hard turning process. Measurement, Elsevier, 2015.

[3] Dudzik, K., The influence of welding parameters on the quality of joints made by FSW of AW-5083 aluminium alloy, In METAL 2016: 25th Anniversary International Conference on Metallurgy and Materials, pp. 694-699, Tanger, Ostrava 2016.

[4] Dyl, T., Starosta, R., Określenie wpływu geometrii i rodzaju materiału płytek skrawajacych na topografię toczonych powłok kompozytowych, Inżynieria Materiałowa, Nr 6, pp. 701-704, 2012.

[5] Dyl, T., Starosta, R., Wptyw geometrii i gatunku plytek skrawajacych na strukture geometryczna toczonych powłok stopowych, Inżynieria Materiałowa, $\mathrm{Nr} 4$, pp. 395-398, 2011.

[6] Labuda, W., Khudoley, A., The influence of burnishing process on surface roughness of stainless steel researched by optical profiler, In METAL 2016: 25th Anniversary International Conference on Metallurgy and Materials, pp. 765-770, Tanger, Ostrava 2016.

[7] Labuda, W., The influence of changing of cutting parameters on temperature and cutting forces during turning process by CCET09T302R-MF insert, Journal of KONES Powertrain and Transport, Vol. 25, No. 1, pp. 249-256, 2018.

[8] Labuda, W., The influence of changing the side angle of the cutting tool by Wiper technology on the value of material ratio parameters of steel applied to marine pump shaft pins, Journal of KONES Powertrain and Transport, Vol. 22, No. 2, pp. 139-147, 2015.

[9] Labuda, W., The influence of cutting inserts geometric on surface roughness of steel applied to sea water pump shafts, Journal of KONES Powertrain and Transport, Vol. 22, No. 3, pp. 133-140, 2015.

[10] Labuda, W., The analysis of cutting tool geometric on cutting forces and surface roughness of steel applied to marine pumps shaft pins, Journal of KONES Powertrain and Transport, Vol. 21, No. 1, pp. 147-152, 2014.

[11] Magri, A., Diniz, A. E., Suyama, D. I., Evaluating the use of high-pressure coolant in turning process of Inconel 625 nickel-based alloy, Proceedings of the institution of mechanical engineers part B-journal of engineering manufacture, Vol. 232, pp. 1182-1192, 2018. 
[12] Sadilek, M., Dubsky, J., Sadilkova, Z., Poruba, Z., Cutting forces during turning with variable depth of cut, Perspectives in Science, Elsevier, 2015.

[13] Starosta, R., Dyl, T., Obróbka wykańczająca natryskiwanych płomieniowo powłok Ni-Al. Ocena zużcia borazonowych ptytek skrawajacych, Tribologia, Teoria i Praktyka, Nr 4, pp. 245-252, 2011.

Manuscript received 10 July; approved for printing 21 November 2019 